\title{
A CONTRIBUTION TO THE SUBDIVISION OF THE PRECAMBRIAN IN SOUTH AMERICA
}

\author{
BENJAMIN BLEY DE BRITO NEVES*, WILSON TEIXEIRA*, \\ COLOMBO CELSO GAETA TASSINARI* e KOJI KAWASHITA*
}

\begin{abstract}
RESUMO UMA CONTRIBUIÇÃO PARA A SUBDIVISÃO DO PRÉ-CAMBRIANO NA AMÉRICA DO SUL. Nas áreas de escudo do continente sul-americano (cerca de $5.000 .000 \mathrm{~km}^{2}$ de extensão) existem cerca de 17.000 determinações geocronológicas disponíveis. Mais de $75 \%$ desse total foi conduzido no Centro de Pesquisas Geocronológicas da Universidade de São Paulo, nos últimos 25 anos. A maioria dos dados é oriunda dos métodos Rb-Sr (ca. 60\%) e K-Ar (ca. 40\%). Os autores tentaram trabalhar esses dados e conectá-los da forma mais coerente possível com o progresso do conhecimento geológico e geotectônico observado nestas últimas décadas. Um dos objetivos essenciais foi tentar esquematizar uma subdivisão atualizada para o Pré-Cambrano do continente e com 'sto contribuir com os propósitos da Comissão Internacional de Estratigrafia (ICS), Subcomissão de Estratigrafia do Pré-Cambriano (SPS), da IUGS. Uma subdivisão tríplice do Eon Proterozóico foi adotada e será discutida no texto. Esta subdivisão apresenta diferenças essenciais, em termos de limites entre eras, com aquela proposta pelo SPS e editada pela ICS, durante o último Congresso Geológico Internacional de Washington. As razoes geológicas para essas diferenças são extensivamente discutidas neste artigo.
\end{abstract}

Palavras-chaves: Geocronologia, subdivisão, América do Sul.

\begin{abstract}
On the shield areas of the South America continent (about 5,000,000 $\mathrm{km}^{2}$ large) there are about 17,000 geochronological determinations available. More than $75 \%$ of this amount has been carried out in the Centro de Pesquisas Geocronológicas da Universidade de São Paulo, CPGeo-USP, in the last 25 years. The majority of these data were accomplished through $\mathrm{Rb}-\mathrm{Sr}(\mathrm{ca}$. 60\%) and $\mathrm{K}-\mathrm{Ar}$ (ca. 40\%) methods The authors tried to work this amount of data on a coherent way according to the progress observed in the geologic and geotectonic knowledge during the last two decades. One of the fundamental goals was to outline an up-to-date subdivision for the Precambrian of this continent, having in mind a contribution to the International Commission on Stratigraphy (ICS), Subcommission of Precambrian Stratigraphy (SPS) of the IUGS. A threefold subdivision for the Proterozoic is adopted and discussed. Such a subdivision differs, in terms of geochronometric boundaries between eras, from that proposed by SPS and published by ICS during the last International Geological Congress in Washington. The geological reasons for these differences are extensively discussed in this article.
\end{abstract}

Keywords: Geochronology, subdivision, South America.

INTRODUCTION The Geochronological Research Center of the University of São Paulo (CPGeo-USP) has recently celebrated 25 years of existence summing up about 13,000 geochronological determinations done and some hundreds of published scientific papers on crustal evolution of the South American continent. Moreover, there is a natural compromise between the CPGeo - USP and the geoscientific community in order to interpret the obtained data and the utilized methods and criteria aiming the best support to a global analysis of the geological evolution of South America during the Precambrian. This compromise is somehow an extension of the purposes of the IUGS International Commission on Stratigraphy (ICS), Subcommission on Precambrian Stratigraphy (SPS), which has for the last two decades addressed the problem of elaborating worldwide a subdivision of the Precambrian.

On the South American Precambrian, comprising $5,000,000 \mathrm{~km}^{2}$ of shield areas, there were, until December 1988, about 17,000 geochronological determinations available, more than three quarters of this amount carried out by CPGeo-USP (Tab. I). The majority of these data was obtained through $\mathrm{Rb}-\mathrm{Sr}(c a .60 \%)$ and $\mathrm{K}-\mathrm{Ar}$ (ca. 40\%) methods. In some specific areas, U-Pb (zircon) and $\mathrm{Pb} / \mathrm{Pb}$ (whole rock) data are available, representing about $1 \%$ of the total amount of radiometric data.

The problem of subdividing the Precambrian has been subject of many discussions and special meetings, and it has always provided a series of different challenges, as summarized by Plumb \& James (1986). Such a subdivision is not only a matter of geochronological data, versus analytical methods versus computing procedures: this kind of problem usually demands additional considerations and cares, such as regional geologic-geotectonic knowledge and the understanding of the meaning and usage of a geologic time subdivision scheme. The steps of the local/regional geologic evolution of rock assemblages should be clear and the scheme of consistent usage in scientific communication (James 1978).

It is necessary to keep in mind that "all (or virtually all) geologic events of potential value for time subdivision, such as orogenies, are not only time-transgressive but also time consuming", as previously stated by Plumb \& James (1986). Thus, age boundaries should be chosen (and understood) to delimit, rather than designate, those events. Subdivisions of the Precambrian time have to have a transitory validity, that is, they should always be replaced by a new one as soon as new and more trustful data are available.

This paper was presented in the 28th International Geological Congress, in Washington, D.C. In the same event the ICS published the 1989 Global Stratigraphic Chart (Episodes, v. 12, $\mathrm{n}^{\mathrm{o}} 2$ ), including a proposed subdivision of the Precambrian, as a result of an inquiry carried out by SPS. Thus, as part of its objectives, the subdivison here presented adopts the ICS chart as reference for comparison and critical analysis.

PREVIOUS WORKS In South America, during the last two decades, many authors have somewhow cared about the Precambrian subdivision, most of them combining chronometric subdivisions and tectonomagmatic cycles (since Almeida 1971). Most of the papers mentioned in table II (IIA and IIB) are indeed excerpts of regional geologic maps; only very few papers have had the prime purpose of contributing 
Table $I-$ Geochronogical data of South America Tabela I - Dados geocronológicos da America do Sul

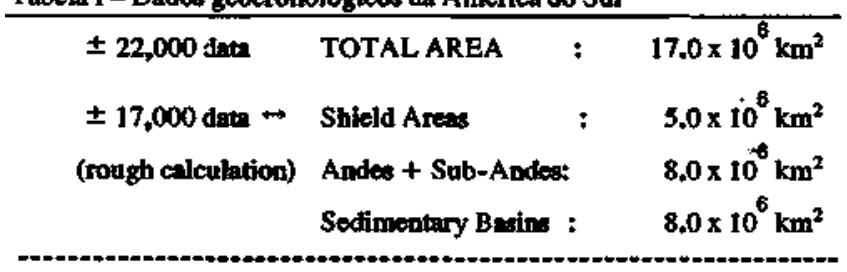

METHODS: Rb/Sr, K/Ar, U/Pb, Pb/Pb, Sm/Nd, Av/Ar

\begin{tabular}{|c|c|c|}
\hline MATN CONTRIAUTIONS & & \\
\hline $\begin{array}{l}\text { CPGeo, IGUSP } \\
\text { Centro de Geocituciay/UFPA } \\
\text { Inst_Geocr.Geol.Isot6pice/TNGEIS }\end{array}$ & $\begin{array}{l}\text { - S.Pauto/Brnzll } \\
\text { - BelGm/Brazil } \\
\text { - B.Aired } \\
\text { Argentins }\end{array}$ & $\begin{array}{r}13,000 \\
500 \\
5,000\end{array}$ \\
\hline SERNAGEOMIN & - Santiago/Chile & 500 \\
\hline
\end{tabular}

\begin{tabular}{|c|c|}
\hline 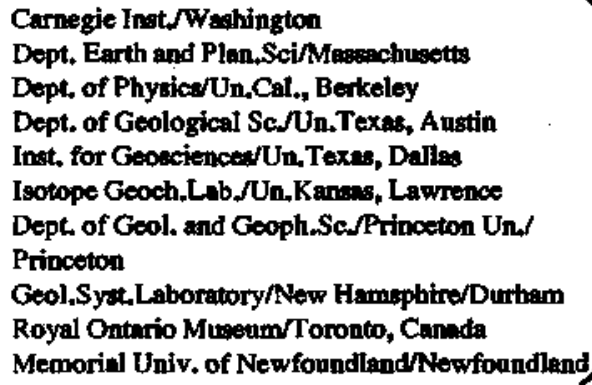 & $\begin{array}{c}\text { A }+ \text { CANADA } \\
\pm 400\end{array}$ \\
\hline
\end{tabular}

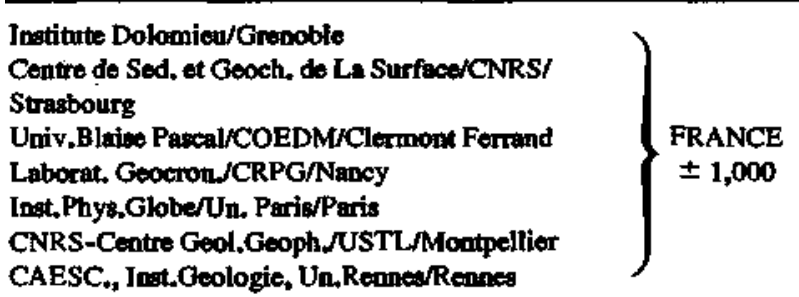

\begin{tabular}{|c|c|}
\hline $\begin{array}{l}\text { Z,W,O, Lab,voor Isotopen-Geologie/Amoterdam } \\
\text { Universite Libre de Bnuxelles } \\
\text { Muce Royal de L'A fitque CentralerTervuren }\end{array}$ & $\begin{array}{l}\text { NETHERLANDS } \\
\text { BELGIUM } \\
\pm 800\end{array}$ \\
\hline 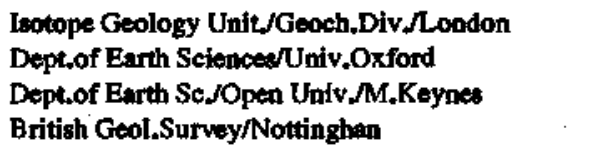 & $\begin{array}{c}\text { ENGLAND } \\
\pm 1,000\end{array}$ \\
\hline G.T.U. Freiburg/Geolg.Inat,Univ., Weat Germany & GERMANY \\
\hline abor.di Geol.Nucl, Universith di Pissa, Italy & $\begin{array}{c}\text { ITALY } \\
\pm 50\end{array}$ \\
\hline
\end{tabular}

to the problem of the Precambrian subdivision.

It is necessary to emphasize that since Almeida (1971) and Schobbenhaus et al. (1984), who integrated less than 1,000, the latter and about 4,000 geochronological data respectively, the differences between both the chronometric boundaries and the schemes of subdivision are comparatively quite few. Recent papers on the same subject, like those of Teixeira et ai. (1989 - Amazonian region) and Mascarenhas et al. (1986 State of Bahia), at regional scale, and that one of Cordani et al. (1988), at continental scale, demonstrate once again that all subdivisions proposed up to now are not far from a wishful agreement.

The subdivision and scheme here proposed is supported by about 17,000 geochronoJogical data, besides the analysis of all previous works. At the same time, such an overview tried to be as close as possible to the improvements which have been made on the geological knowledge itself in the last years in South America.

Regarding the international contributions on the subject of subdivision of the Precambrian, inside and outside ICS/SPS, there is an uncountable amount of published papers, many of them already mentioned by Plumb \& James (1986). Some papers were natural products of specific meetings promoted by ICS/SPS, in which sometimes a Brazilian delegate was present. Actually, the efforts of the ICS/SPS were valorous and they even predate the IUGS.

The papers of Plumb \& James (1986), Plumb (1988), and more recently of Cowie \& Basset (1989) arid Cowie et al. (1989) give a good general overview on the state of art of the problem.

The authors certainly wished that this paper had preceeded the first edition of the IUGS "1989 Global Stratigraphic Chart" (Cowie \& Basset 1989). Nevertheless this was not possible because of a series of other assignments (see Brito Neves 1986, Cordani et al. 1988, Teixeira et al. 1989, Tassinari et al. 1989) that could not be postponed.

Having in mind all the characteristics of this subject, as for instance the temporary validity of all schemes of subdivision, we do hope to be starting the contributions to the next reevaluation and systematization of the Precambrian subdivision. As further discussed in this paper, some important characteristics of the steps of the Precambrian evolution of South America were not satisfactorily covered by the 1989 Global Stratigraphic Chart.

AGE PATTERNS AND IMPLICATIONS FROM THE CONTINENTAL GEOLOGIC-GEOTECTONIC FRAMEWORK An antecedent overview on the general geologic-geotectonic framework of the Precambrian basement of the South American continent (Brito Neves \& Cordani 1989) have already pointed out a clear duality of domains:

a) The Pre-Brasiliano Domain (PBR): the northwest portion of the continent, Amazonian region and surroundings;

b) The Brasiliano Domain (BRD) corresponding to the central and eastern portion of the continent.

In fact, these two pieces of the South-American platform have presented a series of important geologic differences, including primary distribution of their structural lineations.

The PBR segment exhibits mostly NNW-SSE trends, which are products of a much longer history of development according to well separated (in time) stages, since the Early Proterozoic (northeast of the Amazonian craton) up to the beginning of the Proterozoic $(0,9 \mathrm{Ga}$, epi-Sunsas, southwest of the craton).

The BRD domain displays a series of older polygonal segments and terranes (epi-Transamazonian up to epi-Espinhaço) accreted to the Brasiliano (Late Proterozoic) mobile belts. Therefore, the BRD is now exhibiting a much more complex mosaic of structural trends and age provinces.

These two domains (and the BRD domain itself) were amalgamated during the end of the Late Proterozoic - the Brasiliano Cycle - and since then they have shared a common behaviour as part of a single continent (West Gondwanaland) This assembly was disrupted by the continental drift, and th « South American part was further modified with the evolutio of the Andean Chain at its western side.

For these reasons, the BRD domain has had for a long time its continuity recognized in the African counterpart, according to several pre-drift schemes of reconstitution. The PBR domain has been compared, in recent papers, with the blocks of the northern hemisphere (Laurentia, B altica and so on).

During the organization and evaluation of the geochronological (and geologic) data of the Precambrian of the South American Continent that duality has arisen many 
Table IIA - Main contributions to the problem of subdivision of the Precambrian of South America

Tabela IIA - Principais contribuições ao problema da subdivisão do Pré-Cambriano da América do Sul

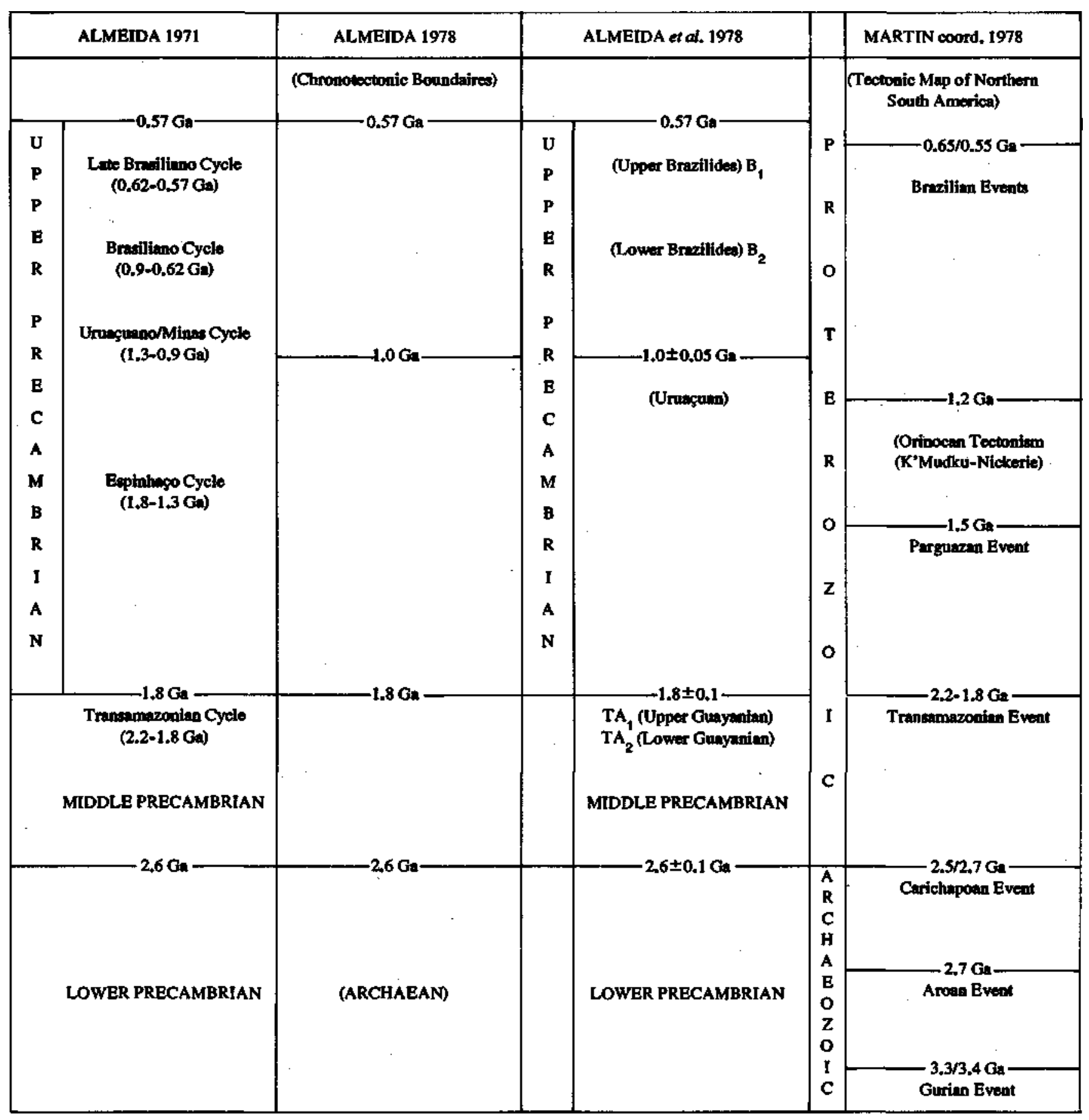

times. Henceforth it becomes necessary to work out two schemes of geochronometric boundaries with the specific differences, as a more suitable solution to better stress the specific Precambrian frameworks and evolutions of PBR and BRD (Tab. III).

Conversely, the tentatives for a single scheme (for the sake of simplification) did not work well because it would hide some important evolutionary aspects that should be emphasized. Even though a single scheme is possible to be accomplished, this procedure and usage sound artificial.

In dealing with the Archean history in both domains the accumulated data are still quite few and a single and common subdivision is an adequate solution. Moreover, only the Jequié
Cycle $(2.7 \mathrm{Ga}-2.5 \mathrm{Ga})$ may be easily assigned to both domains, and up to now no tectonomagmatic cycle can be characterized prior the Jequié Cycle in South America. Therefore, no subdivision of the Archean Eon should be recommended at the moment, and so that one proposed by Plumb by James (1986) was preliminarly adopted here.

The Proterozoic-Phanerozoic limit should still be assumed in a conventional way $(0.57 \mathrm{Ga}$ or $0.54 \mathrm{Ga})$, specially in the Brasiliano domain. Within this domain, in the Cambrian period (and part of the Ordovician period) the latest stages of evolution of the Neoproterozoic orogens are recorded by molassic deposits. The real formation of the first sedimentary cratonic sequences of the continent, as already 
Table IIB - Main contributions to the problem of subdivision of the Precambian of South America

Tabela IIB - Principais contribuições ao problema da subdivisão do Pré-Cambriano da América do Sul

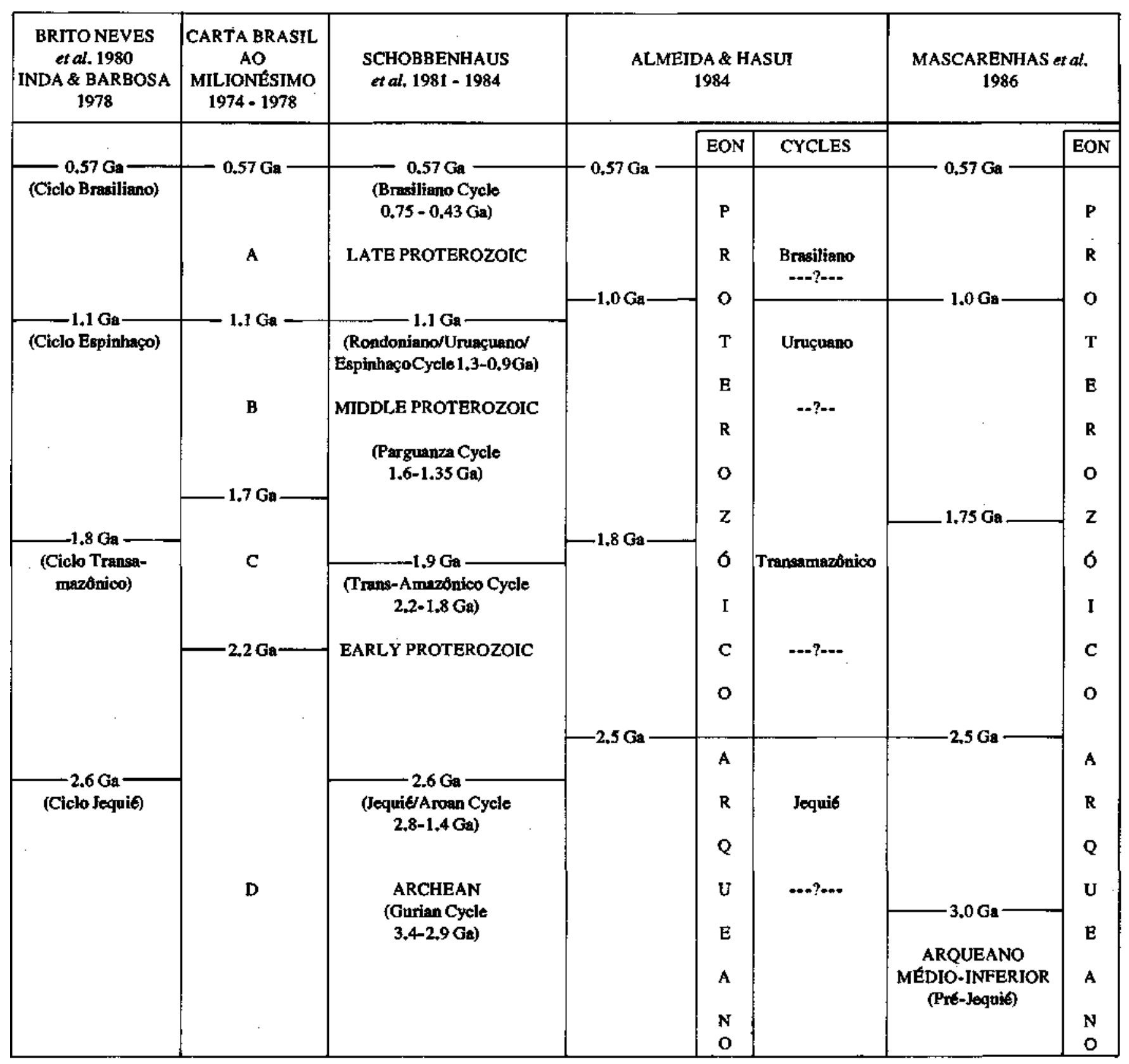

foreseen by Almeida (1969), among others, only commenced in the (Upper) Ordovician and Silurian periods. And this seems also to be true for the most of the Western Gondwanaland continent.

ARCHEAN The Archean of South America does not present singularities to be remarked, even though we cannot say that we know its history in the whole extent. High grade terranes, gneiss-migmatite-granite/granodiorite/tonalite, and a varied group of greenstone and greenstone-like assemblages are the typical Archean representatives, as everywhere. On the other hand, the amount of geochronological data obtained up to now, in this span of time, is comparatively very little. So far the subdivision of the Archean proposed by Plumb \& James (1986) was (experimentally) adopted in this text (Table III), as mentioned prior.

Up to the present, age values older than $3.5 \mathrm{Ga}$ in the span of the Archean I era are practically unknown in the basement of the South America continent, this fact being assumed only as a result of the present stage of knowledge and methodologies in use. Some scarce data $(\mathrm{Rb}-\mathrm{Sr}$ and $\mathrm{K}-\mathrm{Ar}$ do, exist in this span of time, but all of them demand to be ratified with additional analytical procedures.

Geochronological data in the span of the Archean II Era, $3.5-2.9 \mathrm{Ga}$, have gradually been obtained, mostly with $\mathrm{Rb}-\mathrm{Sr}$ and $\mathrm{K}-\mathrm{Ar}$ methods, but there are some $\mathrm{Pb}-\mathrm{Pb}$ and $\mathrm{U}-\mathrm{Pb}$ ages too. Generally, these data were detected as special values (relicts) among several other values of younger Archean and Proterozoic ages. They have been obtained on high grade rocks of basement inliers of Early Proterozoic mobile belts, but without a very important geographic-geologic extent.

As described above, the scarcity of geochronological data in the spans of Archean I and II eras is a fact. But this aspect 
Tabte WI - Proposed subdivision of the Precambrian or South America (CPgeo USP)

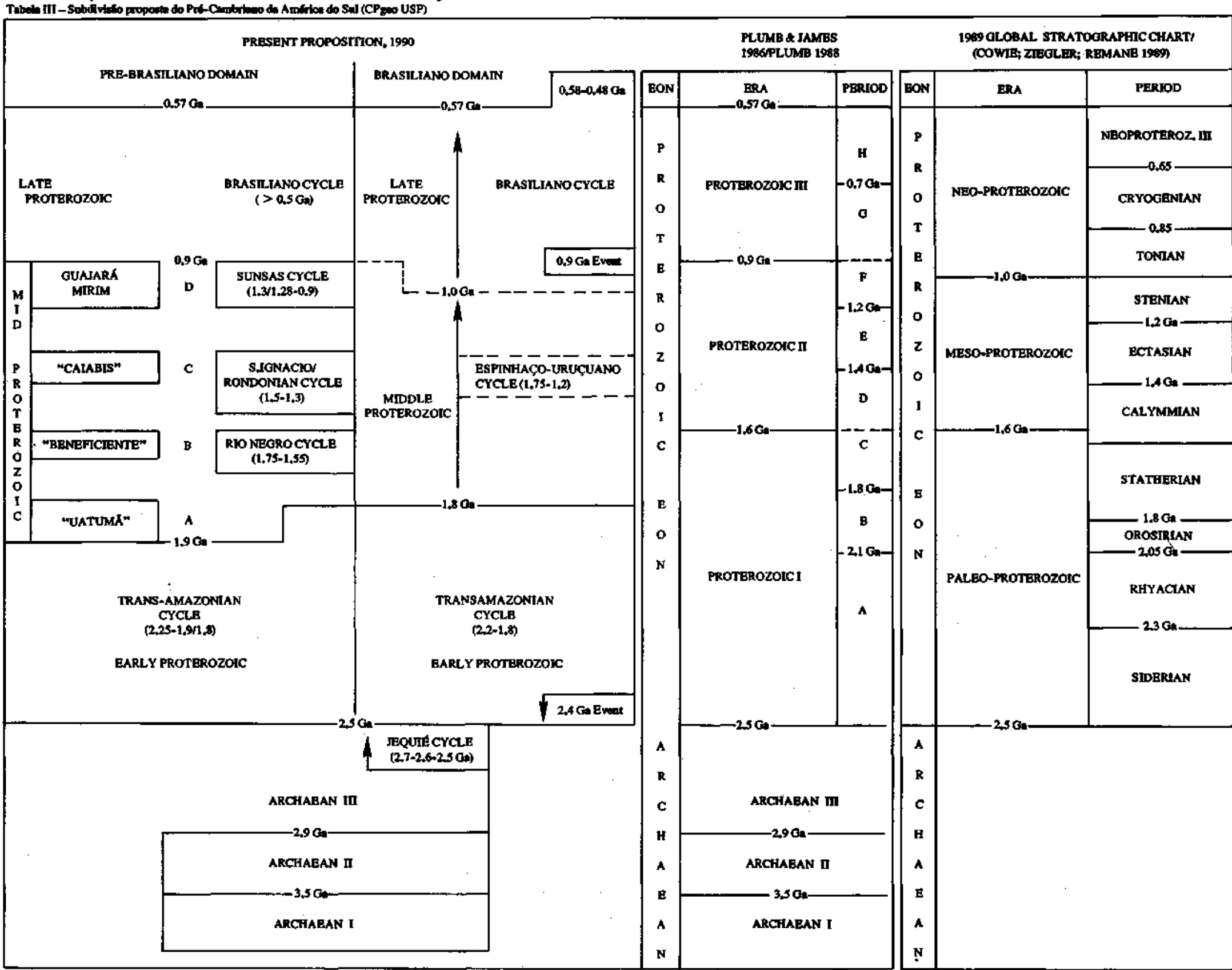


tends to be changed very soon with ongoing research programs, with the introduction of accurate radiometric methodologies in both CPgeo USP and LGI-UFPa. For the moment it is necessary to accept such handicap and the impossibility to state or even to propose any tectonomagmatic cycle prior to the Jequié one at the end of Archean III (Jequié).

For many aspects, the geological and geochronological representation of the Archean III era - 2.9/2.5 Ga - is well illustrated all over the South American shield areas, according to different methods of research. Most of these Archean data have been obtained from high grade terranes of the basement rocks of old cratonic nuclei (Lençóis, Cláudio, Luis Alves, Pakaraima, Xingu, etc.) as well from the basement of the Early Proterozoic mobile belts (Western Bahia, Eastern Bahia, Maroni-Itacaiunas, etc), and (even) from the basement of some Late Proterozoic belts. These data are interpreted as reflecting deformation and metamorphism - stage of orogenesis - of the Jequié Cycle, as proposed by Cordani (1973). Moreover, no previous stages of this tectonomagmatic cycle could yet be distinguished on geochronological terms.

An important continental area should have been accreted during the Jequié Cycle which is showing today a very irregular geographic-geologic distribution within both Proterozoic cratonic segments and mobile belts. That Archean continental landmass (es) was (were) affected by phenomena of rifting, drifting and collisions during different periods of the Proterozoic Eon, and, at present, a paleogeographic reconstitution of those original assemblies of the Archean III terranes is impossible to be figured out.

Some additional comments should be added to the assumed $2.5 \mathrm{Ga}$ time boundary. This age value is representative of a kind of lull succeeding the main tectono-orogenetic events (from $2.8 \mathrm{Ga}$ up to $2.55 \mathrm{Ga}$ from place to place) of the Jequié Cycle. Probably, the initial stages of development of the Early Proterozoic belts may have overlapped this conventional chronological boundary.

On the other hand, there are some evidences of an important local $2.4 \mathrm{Ga}$ event, assigned to medium and high grade metamorphism in the basement of some Early Proterozoic belts of Bahia (see Brito Neves et al. 1980) and Minas Gerais (Teixeira et ai. 1987, Delhal \& Damife 1985). The real meaning and the whole extension of this event is not known yet, and it is only pointed out in the proposed scheme of subdivision with caution, as a separated and later aspect of the Archean history. The possibility of these ages around 2.4 $\mathrm{Ga}$ be related to a precocious event of the Early Proterozoic is difficult, but this idea cannot be ruled out with the present scarcity of data.

EARLY PROTEROZOIC The time-limits here proposed for the Early Proterozoic are between $2.5 \mathrm{Ga}$ and $1.9 \mathrm{Ga}-1.8$ $\mathrm{Ga}$, and largely differ from those limits proposed by the SPS $(2.5 \mathrm{Ga}-1.6 \mathrm{Ga})$, adopted by the IUGS/ICS. Some special geological conditions of the South American (Western Gondwanaland) continent are responsible for our different proposition.

Early Proterozoic mobile belts have been identified in the Pré-Brasiliano domain (Cordani \& Brito Neves 1982, Gibbs \& Barron 1983, Araújo et al. 1988, Teixeira et al. 1989) and in the Brasiliano domain (Brito Neves et al. 1980, Almeida et al. 1981, Teixeira \& Figueiredo 1989, Barbosa \& Fonteilles 1989 etc.) as being part of cratonic nuclei in the Late Proterozoic belts. Within the basement of the Late Proterozoic provinces of the Brasiliano domain (Borborema, Tocantins and Mantiqueira, according to Almeida et al. 1981), Early Proterozoic terranes have usually been recognized. In these cases, because of the overprint of Brasiliano structures, the extent and history of the Early Proterozoic cannot be sufficiently rescued with the available geochronological data (mostly $\mathrm{Rb}-\mathrm{Sr}$ and $\mathrm{K}-\mathrm{Ar}$ ).

Along other continental areas of South America, as in the Brazil - Bolivia frontier (Lomas Maneches assemblages), in the basement of the small cratonic nuclei (São Luis, Luis Alves), and in the basement of the major sedimentary basins, many vestiges of Early Proterozoic terranes have been reported, without enough geological data (see Litherland \& Bloomfield 1981, Litherland et al. 1986, Brito Neves et al. 1984).

Only for the Amazonian region (PBR; the Maroni Itacaiúnas belt) and for the eastern part of the continent (BRD; Eastern and Western Bahia belts), as parts of larger cratonic nuclei, the geological records of the Early Proterozoic are tangible enough to allow suitable geotectonic interpretations.

The main characteristics of these Early Proterozoic areas have been described in many previous papers and they have been interpreted in terms of global tectonics in some recent contributions (e.g. Tassinari et al. 1989, Teixeira \& Figueiredo 1989), and will not be discussed here.

Within the PBR, in the period between $1.9 \mathrm{Ga}$ and $1.8 \mathrm{Ga}$, volcanic and volcanic-sedimentary covers have broadly predominated as it is possible to observe along five different countries of the northern part of South America. All these rock units (Tapajós-Iriri, Surumú, Sobreiro, Iricoumé, Kuyuwini, Dalbana, Cuchivero, etc., according to local names) have usually been included in the so-called "Uatumã Cycle" which developed on a continental area over 1,000,000 $\mathrm{km}^{2}$. Above these volcanic traps and over their basement there is the occurrence of the table-shaped Roraima Supergroup, to which the geochronological data have indicated ages as old as $1.8 \mathrm{Ga}$ (Basei \& Teixeira 1975, Onstottefa/. 1984, Teixeira et al 1989, Renneefa/. 1988).

These two lithostratigraphic assemblages seem to record the first complete volcanic-sedimentary cycle (cratonic covers) over a very extensive just-accreted landmass, product of coalescence processes developed during the Trans-Amazonian Cycle, including older cratonic blocks and the Maroni-Itacaiunas mobile belt. In these conditions, there was an indisputable geologic fact presiding the choice of 1.9 $\mathrm{Ga}$ as time boundary between the Early Proterozoic (assembly of a supercontinent) and the Middle Proterozoic (formation of cratonic stratigraphic sequences) in the PBR. This time boundary is much more than a simple geochronometric mark because it emphasizes a fundamental change in the geological process. However this event has not been synchronous all over the PBR; there are some areas where the final processes of the Transamazonian Cycle (Early Proterozoic evolution) lasted up to $1.8 \mathrm{Ga}$, as table III tries to ilustrate.

By its turn the accretionary and/or collisional processes of the Early Proterozoic belts of the BRD only finished a little bit later, around $1.8 \mathrm{Ga}-1.75 \mathrm{Ga}$, according to Brito Neves et al. (1980) and Mascarenhas et al. (1986), among many other authors. After this time boundary, other geologic processes have taken place in which intraplate/ intracratonic activities were by far predominating. The first volcano-sedimentary cratonic (with other tectonic equivalents) sequence of the processes (on this part of the continent) was the Espinhaço Inferior Group of Bahia and Minas Gerais, for which U/Pb ages are around $1.7 \mathrm{Ga}-1.8 \mathrm{Ga}$, according to Brito Neves et al. (1979) and Machado etal. (1989).

MIDDLE PROTEROZOIC The PBR displays very good records of all steps of the Middle Proterozoic evolution with a reasonable geochronological background. On the eastern part of this domain, there is a succession of intraplate/intracratonic activities succeeding the previously discussed "Uatumã Cycle". At the western portions it has been possible to outline a succession of more cr less parallel orogens (NNW-SSE trends), Rio Negro-Juruena, Rondoniano/S.Ignacio and 
Sunsas-Aguapeí which together integrated the basement of the Amazonian Craton, at the end of the Middle.Proterozoic.

Geological knowledge all over this region should be understood under a reconnaissance point of view, but the geochronological data obtained up to now seem to be congruent and faithful and favoring a four-fold subdivision for the Middle Proterozoic times:

a. The first of these proposed periods (A), 1.9 Ga - 1.8 Ga, was preliminarly justified as encompassing the "Uatumã" and "Roraima" episodes. It certainly demands further geochronological and geological refinement (and subdivision), because it seems to be recording foreland impactogenic reactivations ("Uatumã") connected with late and post-collisional processes of the Maroni Itacaiúnas belt and a subsequent event ("Roraima") of tectonic quiescence. This period had previously been recognized firstly in terms of a "tectonomagmatic reactivation", by Santos (1984, in Schobbenhaus et al. 1984), and secondly as a special metalogenetic epoch, by Tassinari et al. (1984).

b. The following Mid-Proterozoie period (B) $1.75 \mathrm{Ga}-1.55$ $\mathrm{Ga}$, corresponded to the accretionary processes of the Rio Negro Juruena belt of Tassinari (1981). Tassinari et al. (1987) and DalTAgnol et al. (1987), between the Central Amazonian plate (east) and a Brazil-Bolivian plate (westwards). During this orogenetic (orthotectonic) evolution, on the eastern Amazonian cratonic margin there was the development of an important foreland basin (Beneficente) and other correlated basins of interior-type, of which remnants are now forming expressive regional tablelands (Serra do Cachimbo, etc.). Since this time interval, a series of cratogenic A- type granites started piercing the basement of the foreland and sometimes intruded the sedimentary covers. The real tectonic causes of this anorogenic magmatism that proceeded for the third period (see below) is still matter of speculations (Dall'Agnol et al. 1987). It may preliminarly be assumed as intraplate reflex of the orogenetic processes that took place in the Rio Negro Juruena Area.

c. The third period (C) $1.5 \mathrm{Ga}-1.3 \mathrm{Ga}$, displays its geological records along a large area, which includes the cratonized Rio Negro Juruena belt. This period was essentially characterized by the formation of cratogenic covers, and by - products of many different and separated tectonic settings, mostly with clastic and volcaniclastic sediments, and some with subordinate chemical sediments. These rock units, undeformed or slightly deformed, perform a complex lithostratigraphic nomenclature all over the Amazonian craton (see Table IV), all of them requiring adequate geological studies.

Some of these covers present characteristics of mantle-activated rifts processes, including important basaltic magmatism e.g. Caiabis). Some other covers seem to have been originated in tectonic patterns of activated lithosphere, with immature clastic sediments exceeding volcanics (of acid to intermediary character) in abundance.

The already mentioned cratogenic plutonism of the preceeding period (B) had continued along this period (C) without interruptions, associated with occurrences of $\mathrm{Nb}$-Ta, Mo, F, Topaz, Au and Sn (Tassinari et al. 1984).

During this third period, at the western side of the PER, along the Brazil-Bolivian area, there was the development of the San Ignácio Belt (Litherland et al. 1986).

d. The fourth period (D) $1.28 \mathrm{Ga}-0.9 \mathrm{Ga}$, was first characterized by the evolution of the Sunsas-Aguapeí fold belt (west) and by its cratonic correlative covers (Aguapei, Pacaás Novos, São Lourenço) on the foreland area (east), some of them with minor contribution of basalt flows.

An outstanding characteristic of this period was the anorogenic plutonism with typical Tin occurrences, which has alkaline affinities, as described by Bettencourt \& Dall'Agnol (1987) and by Priem et al. (1989). This plutonism marks three
Table IV - Tectonic elements and their main characteristics during the Proterozoic crustal evolution

Tabela IV - Elementos tectônicos e suas principais características durante a evolução crustal proterozóicá

\section{EARLY PROTEROZOIC}

\section{1 - CRATONIC NUCLEI - EARLY PROTEROZOIC CONTINENTAL PLATES}

- Results of aggregation processes of the end of the Archaean, Jequie Cycle.

2 - MOBILE BELTS - LONG LINEAR BELTS, MOSTLY OF VESTIGIAL CHARACTER INCLUDING:

- Tectonic and magmatic reworking of Archean basement

Some undisturbed "basement iniers" (microcontinents? terranes?)

Supracrustal volcanic-sedimentary sequences ("greenstone belts" and similar sequences)

. Fold systems with (Au, U) bearing conglomerates, (Fe, Mn) jaspilites, carbonates ("Witwatersrand type")

Granuhite belts

- Varied granitic activities - several stages, including late to post-tectonic, as striking characteristic

\section{MIDDLE PROTEROZOIC}

1 - CRATONIC NUCLEI/MID-PROTEROZOIC
CONTINENTAL PLATES

- Results of accretionary processes of the Transamazonian Cycle

2 - INTRAPLATE ACTIVITIES PREDOMINATE:

Volcanic traps - Intermediate to acid

Rifts (Mantle-activated and lithosphere-activated)

Syneclises/Tablelands/Foreland Basins

- Cratogenic plutonism ("A" type granitoids), including rapakivis, some alkaline plutons and anorthosites

Basic magmatism associated with lineaments and rift basins: dikes, sills, stocks, minor lava flows

. Lineament activities: shear, tension, etc; tectonite generation

3 - PARTIALLY PRESERVED MOBILE BELTS

- Rio Negro-Juruena (1.75 Ga-1.55 Ga), San IgnácioRondoniano (1.51 Ga-1.3 Ga), Sunsas (1.3 Ga-0.9 Ga), Central Espinhaço (1.75 Ga-1.3/1.2 Ga)

4 - MOBILE BELTS REMOBILIZED DURING THE BRASILIANO CYCLE

. Tocantins (?), Southern and Northern Espinhaco, Araxaídes, Sāo Roque, Setuva/Perau, Embu (?), etc.

\begin{tabular}{ll}
\hline LATE PROTEROZOIC \\
\hline 1 - BREAK-UP OF THE MID-PROTEROZOIC PLATES \\
- Cratons & $\begin{array}{l}\text { Late Proterozic continental } \\
\text { plates } \\
\text { microplates } \\
\text { microcontinents } \\
\text { terranes } \\
\text { reworked portions of the } \\
\text { periphery of the cratonic uclei }\end{array}$
\end{tabular}

\section{2 - MOBHLE BELTS}

- Marginal/miogeosynclinal/miogeoclinal belts Interior/distal/terrigenoos/volcanic-sedimentary belts (several types of tectonic settings, different initial ages) Vestigial belts

- Granite-migmatitic belts (magmatic arcs?)

- Shear belts, deep-fault activities, polycyclical character

- Granitic activities - syn late to post Brasiliano stages. Fissural intrusives and pegmatites 
Table V- Theproterozoic evolution of pre-Brasiliano Domain

Tabela V - A evolução proterozòica dos Domínios pré-Brasilianos

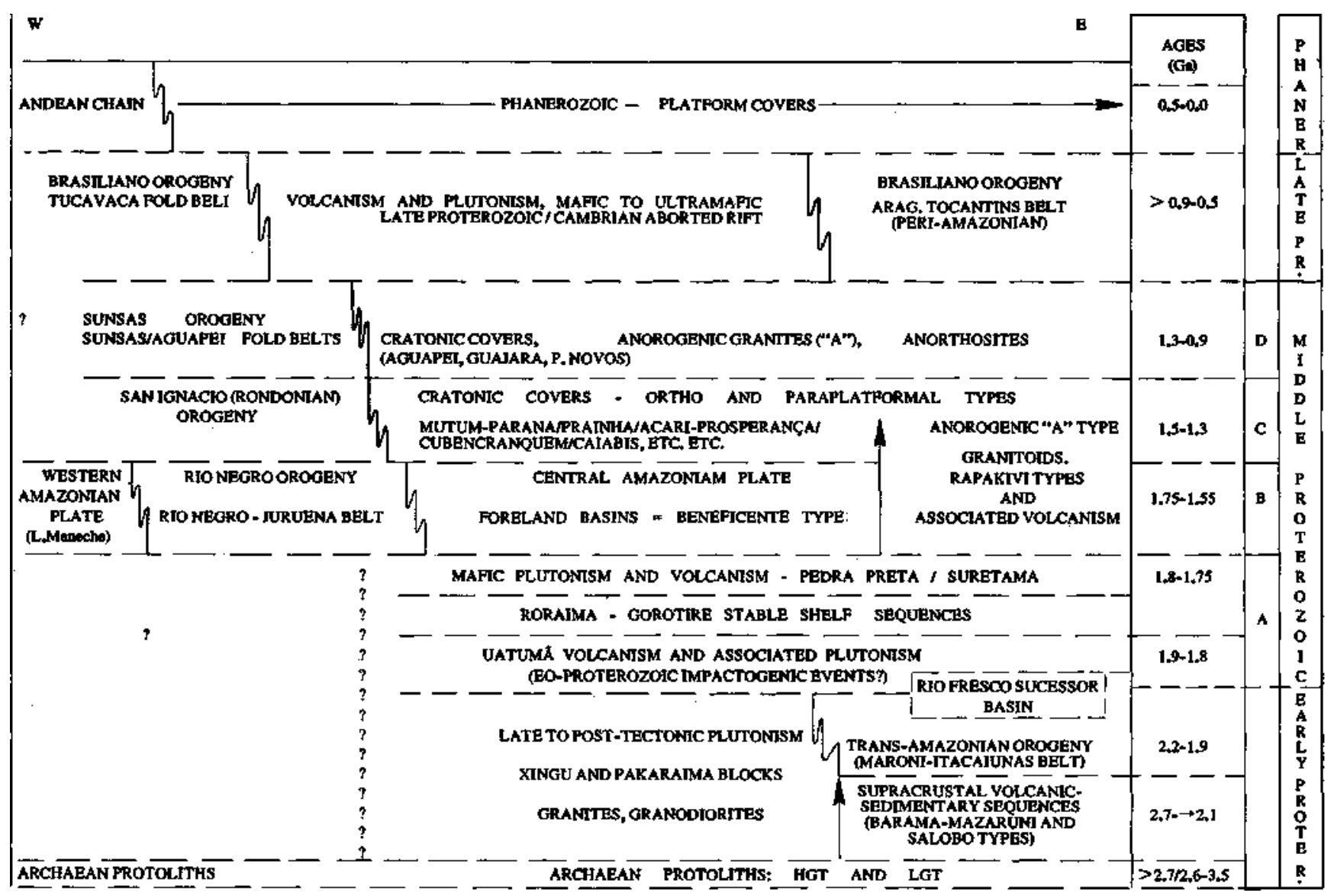

different time intervals $(1.27 \mathrm{Ga}$; $1.055 \mathrm{Ga}$; $0.955 \mathrm{Ga})$. These high level intrusions with $\mathrm{Sn}(\mathrm{W}, \mathrm{Nb}, \mathrm{Ta}, \mathrm{F})$ mineralizations occur all over the area west of the $60^{\circ} \mathrm{W}$ meridian, piercing different kinds of basement rock units. The cratogenic plutonism seems to be controlled by faults and shear zones, and many of the mineralizations are associated with mafic intrusives and both mafic and acid extrusives.

Besides these more impressing and local geological facts, during this fourth period all over the Amazonian craton there were manifestations of other types of events, like shear zones, thermal overprint (rejuvenation of K-Ar ages of older rocks) and some isolated foci of magmatism. Such events have since long been recognized and nominated by several authors ("Orinoquense", "K'mudku", "Nickerie", "Rondoniense", "Jari-Falsino", etc., see synthesis of Amaral 1974). The real tectonic meanings of these broad cratogenic processes are still to be clarified. They may somehow be associated with the orogenetic developments occurring in the neighborhoods of the cratonic area (like Sunsas-Aguapei, Grenville?), as tectonic features of foreland.

In the BRD, the data about the Middle Proterozoic events after the Transamazonian orogenesis are much poorer in details, and for the time being no subdivisions may be proposed.

Along the eastern part of these domains (states of Bahia, Minas Gerais and surroundings) the complete development of cratonic covers (Chapada Diamantina, Natividade) and associated fold belts (Espinhaço, Araxaídes/Uruaçuano) took place since $1.8 \mathrm{Ga}-1.7 \mathrm{Ga}$, with main deformational phases around $1.4 \mathrm{Ga}-1.3 \mathrm{Ga}$, and post - tectonic events lasting up to $1.0 \mathrm{Ga}$ (according to Brito Neves et al. 1979, Fuck etal.
1988, Machado et al. 1989, Cordani et al. 1989, etc.).

Recent data from Fuck et al. (1988) demonstrate that the evolution of the Araxaídes/Uruaçuano belt, where conditions of catazone and mesozone were reached, may be attributed to a continental collision around $1.3 \mathrm{Ga}$ (preliminary stages since $1.8 \mathrm{Ga}$.).

As the scheme of table III tries to show, the distribution time of the previous phases of the Espinhaço or Uruaçuano tectonomagmatic cycle are not known. Only the main phase of deformation and metamorphism is recognized, and it corresponds to the same span of time assigned to the Rondonian/San Ignácio orogenesis.

The Rio Grande fold belt (south of Minas Gerais and northeast of São Paulo) may be a southeastward continuation of the Uruçuano belt. Recent geological and geochronological works carried out in this belt by Vasconcellos (1988) pointed out a similar scheme of evolution (since $1.8 \mathrm{Ga}$ ) with main orogenetic phase around $1.4 \mathrm{Ga}$. Heilbron et al. (1989, in press) pointed out some similar conclusions stating $1.9 \mathrm{Ga}$ as superior limit for age of the metasediments (São João Del Rey and Andrelândia Groups), and main tectono-metamorphic events with ages between $1.3 \mathrm{Ga}$ and $0.9 \mathrm{Ga}$, according to $\mathrm{Rb}-\mathrm{Sr}$ and $\mathrm{K}-\mathrm{Ar}$ determinations.

For the other Mid - Proterozoic fold belts of the Brasiliano domains, quite a few geochronological data may be discussed. Most of these belts were completely affected by the Brasiliano (Late Proterozoic) overprint and so the scattered Mid Proterozoic incidental data available are not enough for a synthesis. Actually, these belts are now encompassed as true Brasiliano structures, included in Brasiliano age provinces. 
LATE PROTEROZOIC The Late Proterozoic is, by all means, the most important Era of the evolution and final assembly of the Precambrian of the South American continent. It is witnessed the general structuration of the $\mathrm{BRD}$ and its amalgamation to the PER.

The PER, as already mentioned, is characterized by the good preservation of the geological frameworks formed up at the end of the Sunsas-Aguapef orogenesis, and this is an adequate reason for the choice of $0.9 \mathrm{Ga}$ as the time boundary for the Late Proterozoic in this domain. After that time the PER worked out as foreland to the surrounding (Brasiliano) fold belts.

The BRD during the Late Proterozoic was characterized by a sorted variety of paleogeographic realms and tectonic settings, which had very different starting points. Actually, the processes of installation of the Brasiliano belts may go back to different episodes in Mid - Proterozoic times $(1.8 ; \pm$ $1.3 ; \pm 1.1 \mathrm{Ga}$ ). There are few Brasiliano belts (or segments of major belts) that had a strict Neoproterozoic age from their initial sedimentary stages to final stages of consolidation.

In other words, data of many Brasiliano belts have quite often demonstrated the importance of a previous Mid Proterozoic history, in terms of sedimentation, volcanism preceeding orogenesis, and even some orogenetic episodes $(1.3 \mathrm{Ga}-1.4 \mathrm{Ga})$. This tendency is tentatively figured out with the use of arrows in table II.

In some Brasiliano provinces, the presence or not of real Neoproterozoic supracrustals is an usual matter of dispute (Tocantins, Seridó, Riacho do Pontal). The Brasiliano overprint and the final Brasiliano framework are not disputable at all.

The main phases of orogeny (and isotopic homogeneization) of the Neoproterozoic belts were naturally diachronous from a place to another, with differences in age up to $200 \mathrm{Ma}(750 \mathrm{Ma}-500 \mathrm{Ma})$. The late and post tectonic events of these belts were diachronous too, but most of them have lasted from the end of the Late Proterozoic (+580 Ma) up to the beginning of the Ordovician period. According to data from the fold belts and surrounding forelands (anorogenic plutonism, foredeep basins, etc. ), most of the Cambrian and part of the Ordovician of South America have witnessed the epilogue of the Brasiliano orogenies.

In these above discussed conditions, both the lower (1.0 $\mathrm{Ga})$ and the Upper $(0.57 \mathrm{Ga})$ Neoproterozoic time boundaries have to be conventional, and no subdivision of this era is possible to be outlined. The choice of these boundaries is made according to the ICS/SPS and it is based upon some other reasons regarding the evolution of the Brasiliano belts (s.s.). Also, it is necessary to acknowledge that these time boundaries had already been proposed by Almeida (1978) without the help of the now available geochronological background.

\section{CONCLUDING REMARKS AND ACKNOWL-} EDGMENTS This paper has the main purpose of summarizing the geochronological data of the Precambrian of South America where about 17,000 geochronological determinations are available, and taking into consideration the recent progress of the geological knowledge itself.

This study and an overview of all previous works lead to the conclusion that the main geochronometric boundaries for the Eons and Eras of the Precambrian are close to a general agreement, at least in terms of the methods (Rb-Sr and $\mathrm{K}-\mathrm{Ar}$ ) up to now used. A further refinement is necessary, but this demands both a change on the scale of work and the introduction of new (Ar-Ar, U-Pb, Sm-Nd) methodologies radiometric.

This proposal and any further schemes of subdivision of the Precambrian of South America have to face their temporary validity: improvements are always required.

We would like to thank many fellows for profitable discussions, namely Oswaldo Siga Jr., Mario Campos Neto, A.R. Fragoso Cesar (Instituto de Geociências, Universidade de São Paulo), Reinhardt Fuck (Departamento de Geologia, Universidade de Brasília), W.R. Van Schmus (University of Kansas, USA). To the unknown referees of this paper, for the comments and suggestions, we would like to express our gratitude.

\section{REFERENCES}

AMARAL, G. 1974 Geologia pré-cambriana da região amazônica São Paulo. 212p. (Tese Livre-Docência, Universidade de São Paulo/IG).

ALMEIDA, F.F.M. de 1969. Diferenciação tectônica da plataforma brasileira. In: CONGR. BRAS. GEOL., 23, Salvador, 1969. Anais... Salvador, SBG. p.29-46.

ALMEIDA, F.F.M. de 1971. Geochronological Division of the Precambrian of South America. Rev. Bras. Geoc., 1(1):13-21

ALMEIDA, F.F.M de 1978 Chronotectonic Boundaries for Precambrian Time Divisions in South America. AnAcad.bras. Ciênc. 50(4):527-535.

ALMEIDA, F.F.M. de (coord.) 1978. Tectonic Map of South America $1 / 5,000,000$. Commission for the Geological Map of the World. MME/DNPM/DGM-UNESCO.

ALMEIDA, F.F.M. de \& HASUI, Y. 1984. O Pré-Cambriano do Brasil. São Paulo, Edgard Blucher. 378p.

ALMEIDA, F.F.M. de; HASUI, Y; BRITO NEVES, B.B. de 1976. The upper precambrian of South America. Bol. IG. USP, 7:45-80.

ALMEIDA, F.F.M. de; HASUI, Y.; BRITO NEVES, B.B. de; FUCK, R.A. 1981. Brasilian Structural Provinces: an introduction. Earth Sci.Rev., 17(1-2):1-29.

ARAÚJO, OJ.; MAIA, R.G.N.; JOÃO, X.S.F.; COSTA, J.B.S. 1988. A megastruturação arqueana da Folha da Serra dos Carajás. In: CONGR. LATINO-AMERICANO DE GEOLOGIA, 7, Belém, 1988. Anais... Belém, SBG/DNPM. p.324-331.

BARBOSA, J.F. 1988. Principais geobarômetros utilizados em granulitos: análises dos resultados de um exemplo do sul da Bahia - Brasil. Rev. Bras. Geoc., 18(2): 162-169.

BARBOSA, J.F. \& FONTEILLES, M. 1986. Examen critique dês resultats furnis par certains baromètre couramment utilises en terrains granulitíques. Examples dês granulites de Bahia - Brésil et de Massif de Agly (France). Butt. Mineral., 109:359-376.

BASEI, M.A.S. \& TEIXEIRA, W. 1975. Geocronologia do território de Roraima. In: CONF. GEOL. INTERGUIANAS, 101, Belém, 1975. Anais... Belém, MME/DNPM. p.453-473.

BETTENCOURT, J.S \& DALL'AGNOLL, R (coord) 1987. The Rondonian tin-bearing granites and associated mineralizations. In: INTERN. SYMP. ON GRANITES AND ASSOCIATED MINERALIZATIONS, Salvador, 1987. Excursion Guides... Salvador, SME-BA. p.49-84.

BONHOME M.G. CORDANI, UG · KAWASHITA, K • MACEDO, M.H.F.; THOMAZ FILHO, A. 1982. Radiochronological age and correlation of Proterozoic Sediments in Brazil. Precambrian Res., 18:103-113.

BRITO NEVES, B.B de 1981. O ciclo brasiliano no nordeste. In: SIMP. GEOL. NORDESTE, 10, Recife, 1981. Atas... Recife, SBG. p.329-337.

BRITO NEVES, B.B. de 1986. Tectonic regimes in the Proterozoic of Brazil. In: SIMP. GEOL. NORDESTE, 12, João Pessoa, 1986. Atas... João Pessoa, SBG. p.235-251.

BRITO NEVES, B.B. de; KAWASHITA, K.; CORDANI, U.G.; DELHAL, J. 1979. A evolução geocronológica da Cordilheira do Espinhaço. Dados novos e integração. Rev. Bras. Geoc., 9(1):71-85

BRITO NEVES, B.B de; CORDANI, U G · TORQUATO, J R.F. 1980. Evolução geocronológica do Pré-Cambriano do Estado da Bahia. Geologia e Recursos Minerais do Estado da Bahia. Salvador. 3:1-101. (Textos Básicos).

BRITO NEVES, B.B. de; FUCK, R., CORDANI, U.G.; THOMAZ FILHO, A. 1984. Influence of basement structures on the evolution of the major sedimentary basins of Brazil: a case of 
tectonic heritage. Journal of Geodynanncs, 1(3-5):495-510.

BRITO NEVES, B.B. de\& CORDANI, U.G. 1989. Geologic evolution of South America during the Late Proterozoic. In: INTERN. GEOL. CONGR., 28, Washington, 1989. Abstracts..., Washington, v.2., p.510-511.

CARTA GEOLÓGICA DO BRASIL AO MILIONÉSIMO 19747 1978. Utilizadas diversas folhas editadas pelo DNPM/MME, Brasília, SCHOBBENHAUS, C. coord., 1974 a 1978

CORDANI, U.G. 1973. Evolucão geológica pré-cambriana da faixa costeira do Brasil entre Salvador e Vitória. São Paulo. 98p. (Tese de Livre-Docência, IG/Universidade de São Paulo).

CORDANI, U.G. 1981. Evaluation tectônica de Ia corteza continental sudamerica y su importância en Ia caracterizaction de províncias uraniferas. In: At. Eng. Agenc., 162(1):3-23.

CORDANI, U.G. \& BRITO NEVES, B.B. de 1982. The geological evolution of South America during the Archaean and Early Proterozoic. Rev. Bras. Geoc., 12:78-88.

CORDANI, U.G.; TEIXEIRÄ, W.; TASSINARI, C.C.G.; KAWASHITA, K.; SATO, K. 1988. The growth of the Brazilian shield. Episodes, 11(3):163-166.

CORDANI, U.G.; KAWASHITA, K.; IYER, S.S. 1989. Pb-Pb, Rb-Sr and K-Ar systematics of rock types in Lagoa Real Uranium Province, South Central Bahia, Brazil. In: INTERN. GEOL. CONGR., 28, Washington, 1989. Abstracts..., Washington, v.l, p. 327 .

COWE, J.D. \& BASSET, M.G. 1989. International Union of Geological Sciences 1989. Global strati graphic chart with geochronometric and magnetostratigraphic calibration. Episodes 12(2). (Supl.).

COWIE, J.W.; ZIEGLER, W.; REMANE, J. 1989. Stratigraphic Commission Accelerates Progress, 1984 to 1989. Episodes, 12(2):79-83.

DALL'AGNOL, R.; BETTENCOURT, J.S.; JOÃO, X.S.J.; MEDEIROS, H.; ROCHA, H.T.; MACAMBIRA, MJ B. 1987. Granitogenesis in the Northern Brazilian Region: a review. Rev. Bras. Geoc., 17(4): 382-403.

DELHAL, J. \& DEMAIFFE, D. 1989. U-Pb Archaean geochronology of the São Francisco Craton (Eastern Brazil), Rev. Bras. Geoc., 15(1):55-60.

FIGUEIREDO, M.C.H. 1989. Geochemical evolution of Eastern Bahia, Brazil: a probable Early Proterozoic subduction related magmatic arc. Journ. of South American Earth Sciences, 2(2): 131-145.

FUCK, A.A.; BRITO NEVES, B.B. de; CORDANI, U.G.; KAWASHITA, K. 1988. Rb-Sr measurements of metamorphic rocks from the Barro Alto Complex, Goiás, Brazil. In: INTERN. CONFER. ON GEOCH. EVOL. OF THE CONT. CRUST. Poços de Caldas, 1988. Extended Abstracts..., Poços de Caldas. p.131-138.

GIBBS, A.K. \& BARRON, C.K. 1983. The Guyana Shield reviewed Episodes, (2):7-14.

HEDBERG, L.D. 1974. Basis for chronostratigraphic classification of the Precambrian. Precambrian Res. 1:165-177.

HEILBRON, M.: GONCALVES, M.L.; TEIXEIRA, W.; TROUW, R.; PADILHA, A.; KAWASHITA, K. 1989. Geocronologia da região entre Lavras, São João del Rey, Caxambu e Lima Duarte, MG. An. Acad. bras. Ciênc. (In press).

INDA, H.A.W. \& BARBOSA, J.F. 1978. Mapa Geológico do Estado da Bahia, escala 1/1.000.000. Salvador, Secret. Minas e Energia Coord. Prod. Min.

JAMES, H.L. 1978. Subdivision of the Precambrian - a brief review and a report on recent decision by the Subcommission on Precambrian Stratigraphy. Precambrian Res., 7:193-204.

LITHERLAND, M. \& BLOOMFIELD, K. 1981. The Proterozoic history of Eastern Bolivia. Precambrian Res. 15:157-179.

LITHERLAND, M.; ANNELLS, R.; APPLETON, J.; BERRANGE, J.; BLOOMFIELD, K.; BURTON, C.; DARBYSHIRE, D.; FLETCHER, C.; HAWKINS, M.; KLINCK, B.; LLANOS, A.; MITCHELL, W.; O'CONNOR, E.; PITFIELD, P.; POWER, G. WEBB, B. 1986. The geology and mineral resources ofth Bolivian Precambrian shield. Nottinghan British Geol. Survey. Overseas Memoir. 9,153p.

MACHADO, N.; SCHRANK, A.; ATRDU, F.R.; CNAVER, L.G.; ABREU, P.A.A. 1989. Resultados preliminares da geocronologia $U-P b$ na Serra do Espinhaço Meridional. 4p. (In press).

MARTIN, C.F. (s/d) Mapa Tectônico de Venezuela. Escala aprox. $J / 5.700 .000$. Ministério de Minas y Hidrocarburos-Caracas.

MARTIN, C.F. (coord.) 1978. Mapa Tectônico - Norte de América dei Sur. Escala 1/2300.000. República de Venezuela - Ministério de Minas y Energia. Caracas, Dirección de Investigaciones Geonalíticas y Tecnológicas.
MASCARENHAS, J.F.; BARBOSA, J.F.; CORDANI, U.G.; SATO, K. 1986. Mapa Geocronológico do Estado da Bahia 1:1.000.000. Secretaria de Minas e Energia, Superintendência de Geologia e Recursos Minerais.

OLSZEWSKY, W.J.; GAUDETTE, H.E.; WIRTH, K.R.; GIBBS, A.K. 1989. The age, origin and tectonics of the Grão Pará Group and associated rocks, Serra dos Carajás, Brazil: Archaean continental volcanism and rifting. Precambrian Rés. 42(2-3): 229-254.

ONSTOTT, T.C.; HÄRGRAVES, R.B.; YORK, D. 1984. Dating of Precambrian diabases dikes of Venezuela using paleomagnetic and $\mathrm{Ar}^{\wedge} \mathrm{O} / \mathrm{Ar}^{3}{ }^{\wedge}$ methods. In: SYMP. AMAZÔNICO, 2, Manaus, 1984. Anais.. Manaus, MME/DNPM. v.2, p.513-518.

PLUMB, K.A. 1988. Geochronologic Subdivision of the Proterozoic proposals by the Subcomission on Precambrian Stratigraphic. In: INTER. SYMP. ON GEOCH. AND MINERALIZAT. OF PROTEROZ. MOBILE BELTS, Tiajin, 1988.Afes<racte...Tiajin, p.73-74.

PLUMB, K.A. \& JAMES, H.L. 1986. Subdivision of Precambrian time: recommendations and suggestions by the Subcommission on Precambrian Stratigraphy. Precambrian Res., 32:65-92.

PRIEM, H.N.A.; BON, E.H.; VERDURMEN, D.A.T.; BETTENCOURT, J.S. 1989. Rb-Sr chronology of Precambrian crustal evolution in Rondônia (western margin of the Amazonian craton), Brazil. Journ. of South American Earth Sciences, 2(2):163-170.

RENNE, P.R.; ONSTOTT, T.C.; JOÃO, X.S.J. 1988. ${ }^{4 \circ} \mathrm{Ar} / 39 \mathrm{Ar}$ and paleomagnetic results from the Guaporé Shield; further implications for the nature of Middle-Late Proterozoic mobile belts of Gondwanaland. In: CONGR. LATINO-AMERICANO DE GEOLOGIA, 7, Belém, 1988. Anais... Belém, p.348-362.

SCHOBBENHAUS, C.; CAMPOS, D.A.; DERZE, G.R.; ASMUS, H.E. 1984. Geologia do Brasil. Texto explicativo do Mapa Geológico do Brasil e da área oceânica adjacente incluindo depósitos minerais. Brasília, DNPM/MME. 501p.

SCHOBBENHAUS, C.; CAMPOS, D.A.; DERZE, G.R.; ASMUS, H.E. 1981. Mapa Geológico do Brasil e da área oceânica adjacente inchando depósitos minerais, escala 1:2.500.000. Brasília, MME/DNPM

TASSINARI, C.C.G. 1981. A evolução geotectônica da província Rio Negro-Juruena na Região Amazônica. São Paulo. 1Olp. (Dissertação de Mestrado, IG/Universidade de São Paulo).

TASSINARI, C.C.G.; SIGA JR. O., TEIXEIRA, W. 1984. Épocas metalogenéticas relacionadas a granitogênese. In: CONGR BRÁS. GEOL., 33, Rio de Janeiro, 1984, Anais... Rio de Janeiro, SBG.p.2963-2977.

TASSINARI, C.C.G.; TEIXEIRA, W.; SIGA JR. O. 1989. Archaean and Early Proterozoic crustal evolution of the Amazonian craton, Brazil. In: INTERN. GEOL. CONGR., 28, Washington, 1989. Abstracts..., Washington, v.3, p.221.

TASSINARI, W.; TEIXEIRA, W.; SIGA JR., O.; KAWASHITA, K.; CORDANI, U.G. 1987. Geologic evolution and evaluation of recent geochronological data in the Amazonian craton. In: IGCP PROJECT 204. Final Meeting. Carajás Extended Abstracts..., Carajás, p.20-31.

TEIXEIRA, W.; CORDANI, U.G.; KAWASHITA, K.; TAYLOR, P.N.; Van SCHMUS, W.R. 1987. Archaean and Early Proterozoic crustal evolution in the southern part of the São Francisco craton. In: INTERN. SYMP. ON GRAN. AND ASSOCIATED MINERAL./ISGAM, Salvador, 1987. Extended Abstracts.. Salvador, p. $37-40$

TEIXEIRA, W. \& FIGUUEIREDO, M.C.H. 1989. Outline on Early Proterozoic crustal evolution in the São Francisco craton, Brazil. In: INTERN. GEOL. CONGR., 28, Washington, 1989. Abstracts... Washington, v.3., p.226-227.

TEIXEIRA, W.; TASSINARI, C.C.G; CORDANI, U.G.; KAWASHITA, K. 1989. A review of the geochronology of the Amazonian craton: tectonic implications. Precambrian Res. 42:213-227.

VASCONCELOS, A.C.B.C. 1988. O Grupo Andrelândia na região a norte de Ouro Fino, MG. São Paulo. 199p. (Dissertação de Mestrado, IG/Universidade de São Paulo).
MANUSCRITO A629

Recebido em 16 de novembro de 1989 Revisão do autor em 21 de fevereiro de 1990 Revisão aceita em 21 de fevereiro de 1990 